\title{
En-Gendering the Couple-Deity Relationship: Clinical Implications of Power and Process
}

\author{
Brandt C. Gardner \\ Oklahoma State University \\ Mark H. Butler \\ Brigham Young University - Provo, mark.butler@byu.edu \\ Ryan B. Seedall \\ Michigan State University
}

Follow this and additional works at: https://scholarsarchive.byu.edu/facpub

Part of the Other Social and Behavioral Sciences Commons

\section{Original Publication Citation}

Gardner, B. C., Butler, M. H., \& Seedall, R. B. (2008). En-gendering the couple-deity relationship:

Clinical implications of power and process. Contemporary Family Therapy, 30(3), 152-166.

\section{BYU ScholarsArchive Citation}

Gardner, Brandt C.; Butler, Mark H.; and Seedall, Ryan B., "En-Gendering the Couple-Deity Relationship: Clinical Implications of Power and Process" (2008). Faculty Publications. 4453.

https://scholarsarchive.byu.edu/facpub/4453

This Peer-Reviewed Article is brought to you for free and open access by BYU ScholarsArchive. It has been accepted for inclusion in Faculty Publications by an authorized administrator of BYU ScholarsArchive. For more information, please contact ellen_amatangelo@byu.edu. 


\title{
En-Gendering the Couple-Deity Relationship: Clinical Implications of Power and Process
}

\author{
Brandt C. Gardner · Mark H. Butler · Ryan B. Seedall
}

Published online: 8 May 2008

(C) Springer Science+Business Media, LLC 2008

\begin{abstract}
Spiritual practices are increasingly accommodated by therapists working with religious couples. While research documents potential benefits, spiritual practices such as prayer may invoke an interpretive couple-God relationship distorted by pathogenic processes in one or both spouses. A survey administered to 78 religious couples examined the influence of power/gender as it relates to couples' harmful triangulation with Deity. Results suggest that harmful triangulation with Deity does occur to some degree in couple relationships, that there are significant differences by gender, and that spouses' tendencies to triangulate are correlated with one another. We discuss these results from a systemic-feminist perspective, and offer some clinical applications for working with religious couples.
\end{abstract}

Keywords Gender $\cdot$ Marital therapy $\cdot$ Power $\cdot$ Spirituality $\cdot$ Triangulation

\section{Introduction}

Understanding couple interaction has long been a goal of family professionals. One model of systemic interaction that has received limited empirical attention is that of three-person systems, or relationship triangles (Deal et al. 1999). Triangulation, first characterized by Murray Bowen (Papero 1995), is the inclusion of a third party to diffuse emotional reactivity and anxiety away from the marital dyad. Such triangulation can either facilitate relationship growth and healing or undermine the couple relationship and problem resolution.

B. C. Gardner ( $\square)$

Human Development and Family Science, Oklahoma State University, Stillwater, USA e-mail: Brandt.Gardner@okstate.edu

M. H. Butler

Marriage and Family Therapy, School of Family Life, Brigham Young University, Provo, USA

R. B. Seedall

Michigan State University, East Lansing, USA

e-mail: seedallr@msu.edu 
In a similar manner, religious couples may triangulate Deity (i.e., a relationship with a Supreme Being) into their marital relationship through specific religious practices (e.g., prayer) during episodes of increased anxiety (Butler and Harper 1994). A small amount of empirical and theoretical literature suggests that relationship triangles involving Deity can be helpful for religious couples (Butler et al. 1998, 2002; Butler and Harper 1994; Griffith 1986). Nonetheless, little research in this area has been done recently, and no study has investigated the potential for harmful dynamics to be invoked when the triangulation of Deity into the marital system represents more of a prejudicial, power-related positioning.

Harmful interactions precipitated through spiritual practices such as prayer may be influenced by power dynamics in the relationship that, in the traditional religious marriage, may be indistinguishably aligned with gender. Systemically conceived, gender is an axis in relationships around which key dynamics, including the distribution of power, are traditionally organized (Goldner 1988). In addition, gender may be hypothesized to mirror and index the hierarchical organization of the marriage relationship. Thus, the interpretive or socially constructed couple-Deity triangle may be significantly and harmfully en-gendered, and may then be linked to stereotypic power arrangements in traditional religious marriages.

This study represents the third in a series of investigations of prayer that have been conducted (Butler et al. 1998, 2002). Whereas the other two emphasize the functionality of spirituality in the lives of some couples and families, there is also a need to explore and further understand the potential for misuses and/or misinterpretations of spirituality in the couple context. The purpose of this research was to examine religious couples' various interpretations and social constructions of the couple-Deity triangle, with a focus on potentially harmful interpretations linked to gender and power. In the following section we outline the potential dynamics of a couple-Deity relationship system.

\section{The Couple-Deity Relationship System}

After being largely disregarded for many years (cf. Richards and Bergin 2005), religiosity and spirituality recently have enjoyed increased clinical and research attention (Anderson and Worthen 1997; Butler et al. 1998, 2002; Fincham et al. 2007; Frame 2003; Griffith 1986; Helmeke and Bischof 2007; Richards and Bergin 2005; Sperry and Shafranske 2005). Interestingly, recent study of spirituality has focused primarily on the processes involved in forgiveness (see Fincham et al. 2006, for a review of literature on marital forgiveness). This is reflected in a relative lack of empirical research in the past five years investigating the role the couple-Deity relationship system and practices such as prayer on clinical outcomes.

Regardless of whether certain spiritual practices or processes receive more attention than others, the importance of clinical awareness regarding the significance of spirituality and/or religion in general for some couples was highlighted by Griffith (1986). He explained that astronomers in the 1800 s could not make sense of the orbit of the planet Uranus. Later, they hypothesized that an unseen gravitational force was exerting its influence on the planet and found the unknown planet Neptune in the predicted position, thereby explaining the behavior of Uranus. Similarly, "the family therapist who looks for God in the family may locate a necessary and unexpected resource for restructuring the family" (p. 618).

Deity's triadic position and involvement in couple relationships is a metaphysical or phenomenological "relationship" that is socially constructed by the members of the couple 
themselves and represents one potential third-party relationship partners may utilize to manage anxiety. Couples often access this relationship through prayer. The majority of research examining prayer has examined its potential as a coping mechanism for a variety of physical and emotional stressors, (for a review see Masters and Spielmans 2007). Indeed, positive effects on well-being from such types of prayer as (1) contemplative/ meditative prayer; (2) ritual prayer; (3) petitionary prayer; (4) colloquial/conversational prayer; and (5) intercessory prayer have been identified (McCullough and Larson 1999; Poloma and Pendleton 1989).

Data thus support the conceptualization of prayer as a mechanism for enacting the couple-Deity relationship system. Accordingly, triangulation involving Deity ranges from those interpretations and constructions of this divine relationship that promote the primary couple relationship in healing ways; those that may be seen as neutral by focusing on an individual's relationship with Deity; and those undermining influences that leave problems unresolved, power dynamics imbalanced, and the relationship fundamentally dependent upon Deity.

\section{Healing Triangulation in the Couple-Deity Relationship}

Butler and Harper (1994) offer a "divine triangle" model for conceptualizing this relationship that combines concepts from Bowenian, structural, and emotion-focused therapy in order to create a comprehensive description of the emotional processes and power dynamics of which triangles are indicative. In essence, they outline that a healing triadic relationship with Deity (1) maintains primary focus on the couple bond while also respecting relationship boundaries (relationship); (2) provides self-awareness and insight into all views and perspectives of an issue (neutrality); and (3) invites responsibility for a resolution of the problem that ultimately benefits both partners in the relationship (responsibility).

Similarly, Butler et al. (1998, 2002) found that, when involved in marital conflict, partners who engaged the couple-Deity system through prayer experienced an enhanced sense of (1) emotional self-validation and partner empathy; (2) mindfulness and personal responsibility for relationship reconciliation and problem-solving; and (3) incremental coaching from Deity. Simultaneously, individuals reported that prayer led to a reduction of negativity, hostility, and emotional reactivity. Thus, these healing processes were felt to lead to conflict resolution and improved relationship dynamics.

\section{Harmful Triangulation in the Couple-Deity Relationship}

Although a number of positive systemic benefits potentially result from triangulating Deity into the couple relationship during times of distress or anxiety, triadic processes also exist that reduce a couple's potential for intimacy and their ability to interact with one another in a constructive, healthy, and independent manner (Umbarger 1983). Alliance or coalition triangles occur when two participants of the triad ally themselves against the third (Butler and Harper 1994; Umbarger 1983). Individual spouses who triangulate Deity in this manner may do so by creating coalitions or alliances against their partner, where "God is on my side." This type of triangulation is described by Rotz et al. (1993) as occurring in couples when one partner believes s/he is more "spiritually correct" than the other person. Such a relationship dynamic creates significant power differentials and may erode marital and family relationships. 
Substitution-intimacy triangles occur as one spouse substitutes the relationship with a third party for that with his or her partner. Usually used as a coping technique, their effects serve to create distance between spouses while creating - sometimes artificial—intimacy between one spouse and the triangled individual. Individual spouses who triangulate Deity in this manner often turn to Deity when they believe their spouse to be unapproachable; sharing problems, frustrations, or difficulties with Deity when they believe their spouse won't care. This type of couple-Deity triangulation is exemplified by the following: "I really like to pray when we're mad at each other because I can ... say what I'm feeling [to God] when I can't say it to my [spouse]" (Butler et al. 1998, p. 471). Thus, while the stability of the relationship is maintained by the diversion of one partner's emotional needs or sense of relationship problems, the emotional closeness that accompanies serious work on relationship issues is not experienced.

Substitution-power triangles occur when a spouse (or couple) absolves him or herself of responsibility for problems and defers relationship solutions to a third party. Couples who triangulate Deity in this manner often will turn problems over to Deity for resolution, assumedly making their lives easier while believing themselves to be "faithful" at the same time. Such a relationship dynamic allows partners to abdicate their responsibility for conflict situations and problem resolution by placing that responsibility on Deity. Again, as with substitution-intimacy triangulation, this type of triadic interaction prevents couples from confronting issues in their relationship that may offer growth experiences and relationship enhancement.

When the relationship with Deity is interpreted by partners as occurring in a harmful manner, one (or both) partner's sense of a positive relationship with Deity may be damaged; their perception of Deity's concern for their spouse and their marriage may be hindered or distorted. Partners may compromise Deity's perceived neutrality or systemic perspective of the situation, and/or place responsibility for problems onto Deity. These harmful dynamics risk undermining each relationship in the couple-Deity system. This is especially true if one partner believes that Deity is aligned with the other person, or if $s /$ he prefers interactional processes with Deity over that with his/her partner for managing emotions and handling problems. In the following section we address the roles of gender and power in perpetuating harmful relationship triangles with Deity.

\section{Gender Dynamics in Spirituality, Religiosity, and Marital Interactions}

A small amount of research and scholarly work has highlighted gender differences in terms of the dynamics involved in a relationship with Deity. For example, Feltey and Poloma (1991) suggest that gender is a strong predictor of intimacy or closeness to God. They explain this "closeness to God" in terms of "the greater propensity of women to be expressive, intimate, and connected in relation to others" (p. 191). In a similar vein, Jacobs (1989) hypothesizes that "masculine identification with autonomy and separateness may act as a barrier to attaining states of relationality that inform spiritual consciousness" (p. 19). An ethnographic study of a denomination anchored in the Judeo-Christian tradition suggests that both men and women pray, but the function of prayer in problem resolution is different: "Men are more often encouraged to confront a problem directly and act on it (after prayerful consideration), while women more often are advised 'simply' to 'pray about it'” (Rose 1987, p. 255).

Such differences in women's and men's approach to prayer may lead to significant discrepancies in their respective experience and triangulation of Deity during marital 
conflict. Men and women may socially construct and interpret their relationships with Deity differently according to each partner's unique relational template. In couple relationships, these potentially substantial differences in the relationships that partners experience with Deity may increase the propensity for harmful triangulation between one or both spouses and Deity, especially when coupled with the emotional reactivity and physiological responses that accompany marital conflict.

Rose (1987) highlights another reason why harmful triangulation occurs in couple relationships: "men and women initiate prayer in situations where they feel that [by themselves] they do not have the power to affect the kind of change that is needed" (p. 255). Rose further hypothesizes that if one spouse in particular feels less empowered, then s/he will be more likely than the other to resort to prayer, and submits that "power relations [within the marriage] may be worked out through prayer" (p. 256). Theoretically, such 'working out' may lead less to resolution of the problem than to its fixation in triadic process and structure (Butler and Harper 1994). Spouses who resort to prayer in the context of power problems in the relationship may be likely to triangulate Deity in a harmful manner as they search for validation, an ally, and/or problem resolution through deferring to Deity.

Research examining power in relationships suggests that women often hold the lowpower position in society and in marriage (Zipp et al. 2004). Although some research has suggested that this status within marriage may be mitigated by increased income (Steil and Weltman 1991), other research has found that gender continues to have a stronger effect on power relations within marriage than income (Tichenor 1999). It is possible that these differences increase the potential for men to form an alliance or coalition triadic relationship with Deity in order to convince their partners of their solutions to problems the couple is facing. There is also a possibility that women who experience low power in their couple relationship might seek alliance with Deity to augment their position. Alternately, women may be more likely to form a substitution-intimacy triangle that will allow them an affiliative experience in which they feel validated and heard. In reality, any number of theoretical speculations based upon gender-linked stereotypes and ideas of traditionally organized religious marriages are possible. The purpose of this study is to analyze empirically the potential for harmful triangulation to occur within couple relationships while also exploring the possible effects of gender.

In conclusion, this literature review has set forth the following ideas: (a) spirituality and religiosity play an important role within the relationship of religious couples, including invoking a couple-Deity triangle; (b) couple-Deity triadic relationships appear to have the potential to function along a continuum ranging from healing to harming effects on the couple relationship; and (c) due to power differentials typical in society and marriage, gender may be an influential component of harmful couple interaction and triangulation with Deity. No research has yet examined how the couple relationship may be influenced by gender-linked dynamics within the context of a couple's prayer-invoked relationship with Deity. This study represents a preliminary effort to understand empirically these couple and gender dynamics.

\section{Method}

\section{Design}

This study utilized a correlational, mail-survey design to measure the potential effects of partner gender on the three types of harmful triangulation: coalition/alliance, substitution- 
intimacy, and substitution-power. Specifically, this study explored questions related to the existence of harmful triangulation in couple relationships and its relationship with gender.

\section{Participants}

Surveys were mailed to 560 recruited spouses (280 couples), of which 230 spouses (115 couples) responded. All returned surveys were included in response-rate calculations, which totaled $41 \%$. Incomplete cases and couple data were excluded from these analyses, leading to a final participant sample of 156 spouses (78 couples). Participants were $41 \%$ $(n=64),{ }^{1}$ Latter-day Saint (LDS), $29.5 \%(n=46)$ Protestant, and 29.5\% $(n=46)$ Catholic. For each couple, both partners shared the same religious affiliation. A post-hoc analysis of the demographic data confirmed an actively religious participant sample, with nearly $82 \%(n=128)$ of participants engaging in individual prayer at least once a day. Additionally, a large majority $(89.2 \% ; n=139)$ of participants reported religious involvement that spanned at least 16 years.

Participants were from 25 different states/territories throughout the U.S. and Canada. Nonetheless, 94\% $(n=147)$ of the 156 spouses who participated were Caucasian. The majority $(73 \% ; n=114)$ of respondents had been married to their current spouse for more than 21 years and had $0(5.1 \% ; n=8), 1(7.7 \% ; n=12), 2(29.5 \% ; n=46), 3(23.1 \%$; $n=36)$ and 4 or more $(34.6 \% ; n=54)$ children. The modal respondent $(64.7 \% ; n=101)$ had completed a college or graduate degree, with male respondents reporting more formal education than female respondents. The majority of the households had an annual income of at least $\$ 45,000(\$ 0-\$ 14,999: 1.3 \%, n=2 ; \$ 15,000-\$ 29,999: 1.3 \%, n=2 ; \$ 30,000$ $\$ 49,999: 17.9 \%, n=28 ; \$ 45,000-\$ 64,999: 24.4 \%, n=38 ; \$ 65,000-\$ 79,999: 9.0 \%$, $n=14$; and $\$ 80,000$ and above; $43.6 \%, n=68)$.

\section{Procedure}

Following approval from a university Institutional Review Board (IRB), participants were recruited via snowball or quota sampling (de Vaus 1995), a non-probability technique that attempts to produce a representative sample without a random selection of participants. As compared with telephone and face-to-face interviews, a mail survey, which affords the participant the time to think, is likely to produce fewer social desirability effects (Dillman 1991), an advantage deemed important in the current study. Undergraduate and graduate students at a large, private university in the Midwest recruited participants for the study. Local religious leaders also were solicited for assistance in recruiting participants.

The initial characterization of participants as religious was made by the recruiting acquaintance. Participation was limited to Christian couples in order to obtain a more homogeneous sample in terms of prayer practices. A 7 year marriage cutoff was used in order to examine a religious sample with a longer marriage history, where spiritual and religious practices and experiences could be presumed to be ritualized in their relationship; and also where the couple had progressed beyond the visionary or honeymoon stage of marriage, presumably reducing demand and social desirability effects.

\footnotetext{
${ }^{1}$ Due to complications in the original demographic data, the n's reported in this section are extrapolations based upon the reported percentages, which were directly calculated from the original data.
} 
Both recruiters and participants were blind to the research question. Participants were told that they had been selected for participation in the study because they met the inclusion criteria of being married at least seven years. Participants also were informed that the purpose of the study was to investigate the practice of prayer as it related to conflict and conflict resolution among married couples. Couples were not informed that perceived religiosity was a selection criterion. Follow-up postcards were sent out from 1 to 5 weeks after the initial mailing.

Table 1 PC-II questions suggesting harmful triangulation

\begin{tabular}{|c|c|c|}
\hline $\begin{array}{l}\text { Triangulation } \\
\text { behavior }\end{array}$ & PC-II questions & Potential power implications \\
\hline $\begin{array}{l}\text { Coalition/ } \\
\text { Alliance }\end{array}$ & $\begin{array}{l}\text { - Sometimes prayer tells me my partner is } \\
\text { right, and that I must drop the issue } \\
\text { - Sometimes I wish prayer would cause my } \\
\text { partner to see that I'm right on this one, so } \\
\text { the conflict would be over } \\
\text { - Prayer leads me to see who's right and } \\
\text { who's wrong in a given situation }\end{array}$ & $\begin{array}{l}\text { Aligning with Deity against one's partner } \\
\text { enhances either high or low power } \\
\text { positions }\end{array}$ \\
\hline $\begin{array}{l}\text { Substitution- } \\
\text { Intimacy }\end{array}$ & $\begin{array}{l}\text { - After praying, it's not as important for my } \\
\text { partner to completely understand my } \\
\text { thoughts and feelings } \\
\text { - It's easier for me to give my true thoughts } \\
\text { to God sometimes than my spouse } \\
\text { - Prayer takes care of my need to be heard so } \\
\text { I can forget about my feelings with my } \\
\text { spouse and just move on } \\
\text { - Prayer pretty much solves most conflict } \\
\text { because I've been able to pour out my } \\
\text { feelings to God } \\
\text { - Most often, I use prayer to feel like my } \\
\text { feelings are being heard rather than to get } \\
\text { help } \\
\text { - I can say things to God that I won't say to } \\
\text { my spouse, and this prevents problems } \\
\text { - When I feel like my spouse doesn't } \\
\text { understand me, I can pray and know that } \\
\text { God will } \\
\text { - When I pray, God heals my heart when my } \\
\text { partner can't or won't }\end{array}$ & $\begin{array}{l}\text { Individuals in low power positions may seek } \\
\text { commiseration or compassion through } \\
\text { Substitution-Intimacy }\end{array}$ \\
\hline $\begin{array}{l}\text { Substitution- } \\
\text { Power }\end{array}$ & $\begin{array}{l}\text { - Prayer's influence brings me to agreement } \\
\text { with my spouse's point of view and thus } \\
\text { avoids further conflict } \\
\text { - When I'm too tired to figure out a solution, } \\
\text { I pray and leave it in God's hands } \\
\text { - When my spouse and I pray, we put our } \\
\text { problems in God's hands } \\
\text { - After prayer, I'm more confident that God } \\
\text { will lead my partner to the right decision } \\
\text { for us } \\
\text { - When I pray, the problems in my marriage } \\
\text { are taken care of }\end{array}$ & $\begin{array}{l}\text { Individuals in low power positions may } \\
\text { abdicate responsibility to Deity through } \\
\text { substitution-power }\end{array}$ \\
\hline
\end{tabular}


Instrument

The Prayer Conflict II (PC-II) questionnaire was originally developed to confirm and expand the findings of a previous qualitative investigation (see Butler et al. 1998). Question development followed standard questionnaire design guidelines (de Vaus 1995; Dillman 1991). The entire questionnaire consisted of 103 closed-ended questions with Likert-ordered answer choices (ranging from 0 to 6) regarding spouses' experience of prayer in the context of conflict. Spouses indicated their degree of agreement or disagreement with each statement. Questions were framed so as to avoid suggestion of a "faithful" versus "unfaithful" response in order to minimize social desirability and demand effects. Pilot testing of the PC-II measure was completed by three religious couples and religious leaders from various denominations in order to assess for and reduce social desirability and demand potential, to increase readability and comprehensibility of the items, and to increase construct validity (see Butler et al. 2002, for more information about the scales of the PC-II not utilized for this study).

\section{Scale Development and Reliability}

In the Butler et al. (1998) qualitative study, some evidence suggesting harmful triangulation was identified in the transcripts. Consequently, 16 questions in the PC-II instrument were developed to assess for prayer-based harmful triangulation (see Table 1 for information on the items and scales of the PC-II used for this study). An internal consistency analysis using Chronbach's alpha was used to establish the reliability measures of the three harmful triangulation scales. The alpha reliability score for the three-item alliance/coalition scale was .53; below the .7 standard (George and Mallery 1999). The low reliability of this scale is likely a statistical artifact of the number of questions in the scale, rather than of poor correlations between items. We proceeded with the analysis on the basis of this assumption, and report these results with the caveat that this scale may not be a reliable measure of this construct. The reliability scores for the eight-item substitution-intimacy scale (.72) and five-item substitution-power scale (.75) were acceptable.

\section{Results}

\section{Data Analyses}

This study sought to understand prayer-based, harmful spouse triangulation with Deity and its relationship with gender. We asked three data-related questions regarding prayer-based harmful triangulation with Deity: (1) Do partners report significant harmful triangulation in their relationship? (2) Are there main effects for religion or gender on spouses' propensity toward harmful triangulation or an interaction between the two? and (3) Is one partner's report of harmful triangulation correlated with his/her partner's report? In this section we outline the statistical analyses used to answer these questions and report our findings. It should be noted here that we elected to use the more conservative estimate of significance $(\alpha=.01$ rather than .05$)$ in order to reduce Type I error.

Question 1. Do spouses report significant harmful triangulation of Deity into their marital relationship? For this question, single-sample (univariate) $t$-tests were used to determine whether spouses deviated significantly from the ideal of the complete absence of harmful triangulation ( 0 on a $0-6$ scale) on each scale. Results for husbands and wives (see Table 2) for all forms of harmful triangulation of Deity were significant (alliance/coalition 
Table 2 Single-sample $t$-tests of deviation from the ideal of no triangulation by scale and spouse

\begin{tabular}{|c|c|c|c|c|c|c|c|c|c|c|}
\hline & \multirow[t]{2}{*}{$n$} & \multicolumn{3}{|c|}{ Alliance/Coalition } & \multicolumn{3}{|c|}{ Substitution-Intimacy } & \multicolumn{3}{|c|}{ Substitution-Power } \\
\hline & & M & SD & $t$ & M & SD & $t$ & M & $\mathrm{SD}$ & $t$ \\
\hline Husbands & 78 & 2.8 & .97 & $24.9 *$ & 3.5 & .89 & $35.2 *$ & 3.3 & 1.1 & $27.8 *$ \\
\hline Wives & 78 & 3.1 & 1.0 & $26.1 *$ & 3.9 & .76 & $44.9 *$ & 3.7 & 1.1 & $30.0 *$ \\
\hline
\end{tabular}

$* p<.001$ two tailed significance

Table $32 \times 3$ ANOVA for differences in harmful triangulation (coalition/alliance, substitution-power, substitution-intimacy) by spouse gender and religious affiliation

\begin{tabular}{|c|c|c|c|c|c|c|c|}
\hline \multirow[t]{2}{*}{ Source } & \multirow[t]{2}{*}{$d f$} & \multicolumn{2}{|c|}{$\begin{array}{l}\text { Alliance/ } \\
\text { Coalition }\end{array}$} & \multicolumn{2}{|c|}{$\begin{array}{l}\text { Substitution- } \\
\text { Intimacy }\end{array}$} & \multicolumn{2}{|c|}{$\begin{array}{l}\text { Substitution- } \\
\text { Power }\end{array}$} \\
\hline & & $F$ & $p$ & $F$ & $p$ & $F$ & $p$ \\
\hline \multicolumn{8}{|l|}{ Between subjects } \\
\hline Religion (REL; Protestant, Catholic, LDS) & 2 & .443 & .644 & 1.815 & .170 & 3.486 & $.036^{*}$ \\
\hline \multicolumn{8}{|l|}{ Within subjects } \\
\hline Spouse Gender (SG) & 1 & 7.513 & $.008 * *$ & 9.976 & $.002 * *$ & 12.134 & $.001 * *$ \\
\hline $\mathrm{REL} \times \mathrm{SG}$ & 2 & .201 & .819 & .493 & .613 & 2.956 & .058 \\
\hline
\end{tabular}

$* p<.05 ; * * p<.01$

triangulation: $p<.001$; husbands' $M=2.8, t=24.9$; wives' $M=3.1, t=26.1$; substitution-intimacy triangulation: $p<.001$; husbands' $M=3.5, t=35.2$; wives' $M=3.9$, $t=44.9$; and substitution-power triangulation: $p<.001$; husbands' $M=3.3, t=27.8$; wives' $M=3.7, t=30.0$ ). Thus, results indicated the presence of at least some degree of harmful triangulation of Deity during conflict.

Question 2. Are there main effects for religion and/or gender on partners' propensity toward harmful triangulation or an interaction between the two? To rule out differences by religious affiliation, $2 \times 3$ analyses of variance (ANOVA) were used to test for differences between the three religious groups and by gender for each type of harmful triangulation. A between-subjects comparison revealed no main or interaction effects for religious affiliation for any of the three scales (coalition/alliance $F=.443, p=.644$, substitutionintimacy $F=1.82, p=.17$, substitution-power $F=3.49, p=.036$ ). However, significant main effects were observed for gender (a within-subjects variable) on the alliancel coalition $(F=7.51, p=.008)$, substitution-intimacy $(F=9.98, p=.002)$, and substitution-power $(F=12.13, p=.001)$ scales. An analysis of the means for males and females reported previously point to the conclusion that wives were significantly more likely to report engaging in the harmful triangulation of Deity than were their husbands (see Table 3). No significant interaction was found between religion and gender.

Question 3. Is one partner's report of harmful triangulation with Deity correlated with his/her partner's report? For this test, a paired correlation test coupled with a two-tailed test of significance for non-directional hypotheses was employed. A significant correlation of husbands' and wives' scores was found for all three types of harmful triangulation. This suggests that husbands and wives engagement in each type of harmful triangulation tended to covary (Alliance/Coalition: $p=.001, r=.38$; Substitution-Intimacy: $p<.001$, $r=.51$; Substitution-Power: $p<.001, r=.43$ ). Also suggested is that husbands' or 
wives' tendencies to triangulate are significantly related to their partner's tendencies. That is, the more one partner tends to acknowledge triangulation, the more the other partner will report triangulation as well.

\section{Discussion}

This research is the third in a series of studies intended to further understand the effects of the couple-Deity relationship accessed through prayer on couple conflict and overall functioning (see Butler et al. 1998, 2002). Although the other two studies analyzed the potentially healing influence of triangulation with Deity, this study explored the potentially harmful triangulation dynamics in religious couples' interpretive invocation and realization of their relationship with Deity during marital conflict. The results of this exploration provide initial empirical support for Bowen's observations of triangulation and his theory of the proliferation of interlocking triangles (Kerr and Bowen 1988), as well as Butler and Harper's (1994) model of a "divine triangle" consisting of marital partners and Deity, and their proposition of harmful triadic interaction during episodes of increased anxiety. There was also evidence of gender-linked differences in harmful triangulation, with wives reporting a greater disposition to engage in harmful triangulation than their partners. Lastly, results indicate that partners' reports of triangulation with Deity during conflict are low to moderately correlated. In this section we discuss some of the implications of these findings.

\section{Assessment of Harmful Couple-Deity Triangulation}

Many religious couples seek professional assistance for marital difficulties, and a growing body of research suggests that such counsel and interventions may play a significant role in enhancing these couples' ability to resolve and recover from marital conflict. Therapists who work with religious couples are advised to conduct a detailed assessment (structured or qualitative) that allows for increased understanding of couples' belief systems, perception of Deity, and use of spiritual practices. Griffith (1986) suggests that the therapist (1) should understand that therapy focuses on the interactions and relationship with God rather than the validity of clients' images or beliefs about God (see also Butler and Harper 1994); and (2) assumes a one-down position and "strives for neutrality, withholding judgment ... so that the [client's] image of God can be elaborated in detail ... even as its integrity is protected by the therapist" (p. 617).

However, problematic interpretation or construction of the couple-Deity system has the potential to threaten the couple relationship and limit positive outcomes. In order for clinicians to prevent such problematic interpretations resulting from spiritual practiceswhether they be invoked independently or at the suggestion of a clinician - therapists must (1) acknowledge that metaphysical systems are real relationship systems from a relationship and interaction standpoint; (2) assess for the potentiality of spiritual practices to be used in a manner harmful to the marital relationship; and (3) be prepared to intervene if such harmful dynamics are observed or suspected.

The findings of this study provide preliminary justification for part of this assessment to include efforts to illuminate "insinuations" of harmful couple-Deity triangulation. This may be accomplished, in part, by gaining an understanding of the structural and processual outcomes of spiritual practices such as prayer: "How do you see your Deity interacting 
with you and your partner during times of conflict?" "How is each of you different after you have prayed?" "How are practices such as prayer used in your relationship?" "How do the subjects of spirituality or religion affect your relationship, especially during times of conflict?"

In sum, findings suggest that, in some relationships, harmful couple-Deity triangulation may (1) be a significant dimension of family organization, pattern, and process; and (2) may subsequently insinuate itself into the couple-Deity system, multiplying and magnifying potentially detrimental distortions. This suggests (3) the need for clinical assessment and attention to triadic process in the couple-Deity system.

\section{Gender-linked Differences in Harmful Triangulation}

Relative to gender-linked differences, we believe that a combined systemic-feminist and triadic process interpretation offers a provocative and compelling explanation of our findings. The systemic-feminist view emphasizes relationship distortions and effects in consequence of power imbalances. The triadic process model offers a view of specific harmful triangulation dynamics that may be spawned in such a context of power-specifically, alliance/ coalition (high- and low-power dynamic), substitution-intimacy (low-power dynamic), and substitution-power (low-power dynamic). Persons in either high- or low-power positions may, respectively, ratify or augment their power position through an alliance/coalition construction of the couple-Deity triangle. Persons in low-power positions, if not inclined to maneuver for leverage, may abdicate, through substitution-power triangulation, or find commiseration and compassion through substitution-intimacy triangulation.

This perspective coincides with that of Rose (1987), who asserts that "men and women initiate prayer in situations where they feel that they do not have the power to affect the kind of change that is needed" (p. 255). Rose narrowed her hypothesis somewhat by suggesting that "if women feel less empowered, then it is likely that they will resort more often than men to prayer" (p. 255). In this way, "power relations" (p. 256) are negotiated in the marital relationship through the couple-Deity triangle. Yet, when power becomes a substrate of the couple-Deity triangle, it is our supposition that it is at high risk for yielding to the process distortions characteristic of harmful triangles, regardless of couples' overt awareness of Deity's inherent healing position vis a vis their marriage. Interpretations and social constructions of Deity may succumb to and be distorted by power.

From a clinical standpoint, we also recommend that therapists watch for couple interactions or partner requests that offer some insight into the nature of couple-Deity triangulation in clients' lives and the potential power imbalances that precipitate or result from these dynamics. For example, in a first session of marriage therapy, the wifeunprompted by any contextual cues or direct inquiry from the therapist, and tinted with animus-demanded that "God and/or religion be left out of therapy." Such a demand redflags the couple-Deity system as possibly harmfully triangulated in the marriage. The therapist inquired in a non-stigmatizing way regarding that demand, wondering if the request hinted that "God had been used in a punishing, manipulative, or destructive way." The spouse confirmed that "God" indeed had been so insinuated into the marriage. She affirmed that "God has been just a club to hit me over the head with." In such instances, ignoring the couple-Deity system in therapy is untenable, as it leaves observable destructive dynamics unchecked.

In addition, partners who report such dynamics as Deity (or spiritual practices) "resolving our problems for us," or "helping us avoid conflict because I can talk to God 
sometimes instead of my partner," or "helping me convince my partner that I know what is best for us" may indicate some risk of dynamics that may be harmfully insinuated into the couple-Deity system. Once implanted there, couple-Deity patterns can subsequently reinforce and entrench a substrate of power in the marriage through the imprimatur of acceptability of attending religious practice. Therapists should note partners' tendencies to seek leverage-solutions, validation, or partnership—by invoking extramarital triadic systems.

\section{The Systemic Effects of Harmful Triangulation}

In conjunction with the results above, the finding that partners' self-reports of engaging in couple-Deity triangulation are low to moderately correlated provides insight into the systemic phenomenon of triangulation. In other words, there appears to be a relationship between one partner's harmful triangulation with Deity and his/her partner's triangulation efforts. Because triangulation typically occurs in response to anxiety, partners who experience similar levels of distress during conflict might be those most highly correlated for harmful triangulation. It also could represent those relationships where a fragile balance of power exists, with each partner seeking to triangulate Deity during conflict in order to enhance their power in the relationship.

Despite the findings of some degree of systemic effects, the reports of harmful triangulation with Deity from a number of couples in this sample were not related to each other. In keeping with the previous explanation, this could be explained by a more pronounced imbalance of anxiety and/or power in the relationship. If only one partner is seeking to triangulate Deity, that potentially indicates that $\mathrm{s} / \mathrm{he}$ is experiencing more distress than his/ her partner or that $\mathrm{s} / \mathrm{he}$ is seeking to enhance a position of power in the relationship. The partner who is favored by the power imbalance or feeling less distress feels less need to triangulate Deity. Thus, from a clinical standpoint, triangulation provides a valuable indication that systemic imbalances of anxiety, distress, and/or power may exist in a couple relationship and may need to be addressed.

\section{Limitations and Implications for Future Research}

In considering these findings, the limitations of this research need to be acknowledged. The exploratory nature of this study dictates that these findings are more suggestive than definitive, and we encourage readers to use their review of the religious affiliation, ethnic, and other demographic characteristics of our sample to appropriately delimit the generalizability of our findings. The self-report nature of the data also limits the reliability of the findings, and the alliance/coalition triangulation findings need to be replicated with a statistically reliable scale. Furthermore, the small differences in means for wives and husbands suggests that it may not be gender alone that is responsible for the observed effects, but that there may be additional influences involved.

Such questions and limitations should be addressed in future research. We recommend using a methodology similar to the one employed in this study to assess other religious groups and thereby understand potential harmful triangulation for an increasingly diverse population. In addition, this study investigated potential harmful couple-Deity triangulation among couples who were perceived as religious. There was no distinction made between harmful triangulation dynamics for distressed and non-distressed couples. It would be important to 
confirm empirically the idea that harmful couple-Deity triangulation increases with couple distress. Observational or qualitative research in this area would also expand the richness of data and enhance the understanding of the couple-Deity relationship system.

Finally, the primary focus of this article has been on the existence of harmful triangulation dynamics with Deity and their assessment in therapy. However, there is a great need for empirical research to investigate potentially effective therapeutic interventions for couples engaging in harmful triangulation. For example, we suggest empirically researching the potential of inductive process (Butler and Bird 2000; Butler and Wampler 1999) and enactments (Butler and Bird 2000; Butler and Wampler 1999) as core interventions when working with problematic power and triangulation dynamics. Enactments are therapist behaviors that stimulate and guide direct couple interaction while maintaining the focus on the couple relationship rather than the therapist. Within this framework, a therapist coaches partners to use inductive process and understand each other's perspective and experience. However, although a great deal of conceptual potential exists for enactments to be utilized with partners experiencing harmful triangulation and power imbalances, empirical work is needed to investigate and confirm their utility.

\section{Conclusion}

Despite its limitations, this study makes a unique contribution to the growing body of research examining spiritual/metaphysical dynamics that occur in marital and family relationships, and provides clinicians who work with religious clients a greater understanding of the potentially harmful manifestations of spiritual practices in such relationships. Independent and separate from the validity of a couple's shared faith and/or theology is the issue of whether partners organize the couple-Deity system in healing or harmful ways. Spouses may be unaware of the very real, negative effects of harmful triangulation for the marriage. Helping professionals who work with religious couples within a religious/spiritual framework or who invite such couples to incorporate spiritual practices as part of their conflict resolution rituals (Butler et al. 2002) should be advised to assess for potential problematic interpretations and constructions of the couple-Deity system and the empirical outcomes for the marriage. This type of evaluation would likely best take place within a complete spiritual assessment as described above.

Understanding each spouse's perceived relationship with and experience of Deity will be paramount to assessing whether the potential exists for religious/spiritual practices to be used as healing interventions or whether they will be experienced as harmful to relationship process. Therapists and educators can help clients enhance their experience with spiritual interventions by inviting them to consider that, due to its interpretive, socially constructed dimensions, the couple-Deity system is not immune from harmful distortions and invocations. They can be helped or referred to ecclesiastical leaders who can assist them in successfully navigating the couple-Deity system and avoiding harmful triangulation. We invite future research into this important dimension of couples' and families' shared lives and believe that therapists can neither afford to underestimate or clinically ignore the effects of religiosity and spirituality in couple and family relationships.

\section{References}

Anderson, D. A., \& Worthen, D. (1997). Exploring a fourth dimension: Spirituality as a resource for the couple therapist. Journal of Marital and Family Therapy, 23, 3-12. doi:10.1111/j.1752-0606. 1997.tb00227.x. 
Butler, M. H., \& Bird, M. H. (2000). Narrative and interactional process for preventing harmful struggle in therapy: An integrative empirical model. Journal of Marital and Family Therapy, 26, 123-142. doi: 10.1111/j.1752-0606.2000.tb00284.x.

Butler, M. H., Gardner, B. C., \& Bird, M. H. (1998). Not just a time out: The change dynamics of prayer for religious couples in conflict situations. Family Process, 34, 451-478. doi:10.1111/j.1545-5300. 1998.00451.x.

Butler, M. H., \& Harper, J. M. (1994). The divine triangle: God in the marital system of religious couples. Family Process, 33, 277-286. doi:10.1111/j.1545-5300.1994.00277.x.

Butler, M. H., Stout, J. S., \& Gardner, B. C. (2002). Prayer as a conflict resolution ritual: Clinical implications of religious couples' reports of relationship softening, healing perspective, and change responsibility. American Journal of Family Therapy, 30, 19-37. doi:10.1080/019261802753455624.

Butler, M. H., \& Wampler, K. S. (1999). Couple-responsible therapy process: Positive proximal outcomes. Family Process, 38, 27-54. doi:10.1111/j.1545-5300.1999.00027.x.

de Vaus, D. A. (1995). Surveys in social research (4th edn.). Australia: Allen \& Unwin.

Deal, J. E., Hagan, M. S., Bass, B., Hetherington, E. M., \& Clingempeel, G. (1999). Marital interaction in dyadic and triadic contexts: Continuities and discontinuities. Family Process, 38, 105-115. doi: 10.1111/j.1545-5300.1999.00105.x.

Dillman, D. A. (1991). The design and administration of mail surveys. Annual Review of Sociology, 17, 225-249. doi:10.1146/annurev.so.17.080191.001301.

Feltey, K. M., \& Poloma, M. M. (1991). From sex differences to gender role beliefs: Exploring effects on six dimensions of religiosity. Sex Roles, 25, 181-193. doi:10.1007/BF00289853.

Fincham, F. D., Hall, J., \& Beach, S. R. H. (2006). Forgiveness in marriage: Current status and future directions. Family Relations, 55, 415-427.

Fincham, F. D., Stanley, S. M., \& Beach, S. R. H. (2007). Transformative processes in marriage: An analysis of emerging trends. Journal of Marriage and Family, 69, 275-292. doi:10.1111/j.1741-3737. 2007.00362.x.

Frame, M. W. (2003). Integrating religion and spirituality into counseling. Pacific Grove, CA: Brooks/Cole.

George, D., \& Mallery, P. (1999). SPSS for Windows step by step: A simple guide and reference. Boston, MA: Allyn and Bacon.

Goldner, V. (1988). Generation and gender: Normative and covert hierarchies. Family Process, 27, 17-31. doi:10.1111/j.1545-5300.1988.00017.x.

Griffith, J. L. (1986). Employing the God-family relationship in therapy with religious families. Family Process, 25, 609-618. doi:10.1111/j.1545-5300.1986.00609.x.

Helmeke, K. B., \& Bischof, G. H. (2007). Couple therapy and spirituality and religion: State of the art. Journal of Couple and Relationship Therapy, 6, 167-179. doi:10.1300/J398v06n01_14.

Jacobs, J. L. (1989, October). Religious experiences among men and women: A gender perspective on mystical revelation. Paper presented at the Society for the Scientific Study of Religion annual meeting, Salt Lake City, UT.

Kerr, M. E., \& Bowen, M. (1988). Family evaluation. New York: W. W. Norton \& Co.

Masters, K. S., \& Spielmans, G. I. (2007). Prayer and health: Review, meta-analysis, and research agenda. Journal of Behavioral Medicine, 30, 329-338. doi:10.1007/s10865-007-9106-7.

McCullough, M. E., \& Larson, D. B. (1999). Prayer. In W. R. Miller (Ed.), Integrating spirituality into treatment (pp. 85-110). Washington DC: American Psychological Association.

Papero, D. V. (1995). Bowen family systems and marriage. In N. S. Jacobson \& A. S. Gurman (Eds.), Clinical handbook of couple therapy (pp. 11-30). New York: Guilford Press.

Poloma, M. M., \& Pendleton, B. F. (1989). Exploring types of prayer and quality of life: A research note. Review of Religious Research, 31, 46-53. doi:10.2307/3511023.

Richards, P. S., \& Bergin, A. E. (2005). A spiritual strategy for counseling and psychotherapy (2nd edn.). Washington, DC: American Psychological Association.

Rose, S. D. (1987). Women warriors: The negotiation of gender in a charismatic community. Sociological Analysis, 48, 245-258. doi:10.2307/3711521.

Rotz, E., Russell, C. S., \& Wright, D. W. (1993). The therapist who is perceived as "spiritually correct": Strategies for avoiding collusion with the "spiritually one-up" spouse. Journal of Marital and Family Therapy, 19, 369-375. doi:10.1111/j.1752-0606.1993.tb00999.x.

Sperry, L., \& Shafranske, E. P. (2005). Spiritually oriented psychotherapy. Washington, DC: American Psychological Association.

Steil, J. M., \& Weltman, K. (1991). Marital inequality: The importance of resources, personal attributes, and social norms on career valuing and the allocation of domestic responsibilities. Sex Roles, 24, 161-179. doi:10.1007/BF00288889. 
Tichenor, V. J. (1999). Status and income as gendered resources: The case of marital power. Journal of Marriage and Family, 61, 638-650. doi:10.2307/353566.

Umbarger, C. C. (1983). The terms of structural family therapy. In V. D. Foley (Ed.), Family therapy: Theory, practice, and technique. New York: Grune \& Stratton.

Zipp, J. F., Prohaska, A., \& Bemiller, M. (2004). Wives, husbands, and hidden power in marriage. Journal of Family Issues, 7, 933-958. doi:10.1177/0192513X04267151. 